\title{
Current Status of siRNA Delivery Technology and siRNA Drug Develop- ment
}

\author{
T. Urakami and N. Oku*
}

Department of Medical Biochemistry, University of Shizuoka, Japan

\begin{abstract}
In the past decade, therapeutic potential of RNA interference (RNAi) and its application to human diseases were widely discussed in the related fields of biology, medical sciences, and pharmaceutical sciences. In course of these research and developing processes, efficient transduction of small interfering RNA (siRNA) into target cells is one of the most significant breakthroughs in revealing the feasibility of siRNA-mediated therapies. From the aspect of new siRNA derived drug development, drug delivery system (DDS) holds the key to success. Many studies in the field of DDS have revealed the principles of administration, distribution, metabolism, and excretion of drug carriers in living bodies. Furthermore, these principles put ideas of the theoretical formulation adapted to use in local and systemic administration of siRNA. In this review we focused on the current technology of DDS and its importance upon realizing the therapeutic use of siRNA.
\end{abstract}

\section{INTRODUCTION}

Gene medicines have been expected to be either molecular targeting medicines or personalized drugs. After mapping of human genome, this aspect becomes more realistic. In the past, anti-sense oligodeoxynucleotides (ODNs) were widely investigated, although it required quite a few amounts of the agents to reduce of target protein expression. Accordingly, researchers acknowledged the discovery of small interfering RNA (siRNA) which silenced target genes with only a small amount as a landmark. siRNAs consisting of shorter than 30 nucleotide double-stranded RNA assemble the RNA-induced silencing complex (RISC), and lead the cleavage of the target complementary mRNA. Those could be used as potent suppressant against sequence-specific gene expression in mammals [1,2], and expected to be a potential therapeutic resolution of a variety of diseases [3]. The therapeutic target of siRNA is extensively obtainable, and assumed to be applicable for wide range of diseases, including viral infection [4], genetic and non-genetic diseases [5,6]. However, in order to be recognized as a practical application to human diseases, siRNA must meet the criteria of pharmacodynamics, pharmaco-kinetics and toxicokinetics as therapeutic agents, like other small-molecule drugs and biological agents. From the viewpoint of new siRNA-derived drug development, carrier system of the gene medicine, in other words, drug delivery system (DDS) is one of the crucial technologies. This review highlights the current technology of siRNA delivery of into the target cells.

\section{DEVELOPMENT OF NUCLEIC ACID-DERIVED MEDICINE}

The effort to develop the nucleic acid medicine such as antisense ODNs [7] and ribozymes [8] has been carried on, before the finding of siRNA. Antisense ODNs suppress sequence-specific gene expression with single chain RNA, DNA, or chemically modified their analogues, possessing complimentary base sequence of targeted messenger RNA.

*Address correspondence to this author at the Department of Medical Biochemistry, University of Shizuoka, Japan; E-mail: oku@u-shizuka-ken.ac.jp
In 1998, FDA approved the first antisense drug Vitravene ${ }^{\circledR}$ (Fomivirsen) [9], a product of Isis Pharmaceuticals and Novartis Ophthalmics. Vitravene is injected intravitreally for the treatment of cytomegalovirus retinitis. Currently, a large number of antisense drugs are on clinical trial [10]. One of the disadvantages associated with ODNs as gene medicine is that a number of ODNs should be introduced in a cell for obtaining relevant gene silencing.

\section{CHEMICALLY SYNTHESIZED SIRNAS AND SIRNA GENERATING VECTORS}

In 2001, Tuschl et al. reported that chemically synthesized 21 base-pair double-stranded RNA molecules suppressed the target gene with high specificity [1]. Since then, chemically synthesized siRNA has been widely used for biological researches to identify gene functions. Chemically synthesized siRNA can be modified with functional group by chemical reaction for improving the stability in vivo and reducing non-specific gene suppression. 2'-OH modifications on the ribose ring of siRNA increased the persistence of RNAi as compared with wild-type siRNAs. RNAi was also induced with chemical modifications that stabilized interactions between A-U based pairs, demonstrating that these types of modifications may enhance mRNA targeting efficiency in allele-specific RNAi [11,12]. The duration of effective specific-gene silencing by chemically synthesized siRNA in cell is a couple of weeks at the longest $[13,14]$.

siRNA encoded on gene expression vector was developed to cover the insufficiency of chemically synthesized siRNA. Plasmids that encode DNA templates of two complimentary short RNAs for the synthesis of siRNAs were reported [15]. Some other groups also reported successful application of short hairpin-RNA (shRNA) encoding plasmid DNA. The transcribed shRNAs were effectively silenced the genes of interest [16-18]. siRNAs coded in plasmid DNA vector (double-stranded close circular DNA) [19-21] or viral vector (adenovirus, retrovirus, lentivirus, etc.) [22] are constantly transcribed siRNA in the nucleus of host cells and transcripts are transported to the cytoplasm. 
Viral vectors may be useful for systemic delivery of siRNA and could provide tissue-specific and high-efficient siRNA expression, but bring a unique set of risks and safety concerns. In most non-viral carriers, siRNA or shRNA in plasmid DNA forms complexes with carrier components to improve the stability and transfection efficiency in vivo [2325]. Development of gene transfection carriers could deliver siRNA to the target site. The first requisite for the success of non-viral carrier siRNA in the therapeutic the application is development of siRNA transfection carriers.

\section{BIOLOGICAL BARRIER TO SIRNA DELIVERY AND DDS}

In order to develop and perform gene-silencing experiment based on siRNA technology in vivo and further therapeutic use of siRNA, DDS is one of the most important issues. In DDS for siRNA, drug carriers actually face many obstacles to overcome. Basically, double stranded RNA including siRNA can be easily suffered from enzymatic degradations by ribonuclease (RNase) and is not stable in blood circulation. Non-viral carries are known to interact with many organs including immune system and reticuloendothelial systems.

Of course, the first important step of DDS is to choose effective administration route; local or systemic for each therapeutic application. DDS for local administration can reduce problems that might occur in the systemic administration and is more practical in some cases [3]. However, there are many diseases that require the systemic administration and therefore the development of DDS for systemic administration allows the treatment of disorders with no effective treatment modality is required.

\section{GLOMERULAR FILTRATION AND CAPTURE IN ORGAN}

Capillary blood vessel is classified in two types by its structure, fenestrated capillary or non-fenestrated capillary. Fenestrated capillary possess a number of 70-100 nm pores in intercellular junction of capillary endothelium [26]. Molecular weight of siRNA is about 13,000 Da and these molecules are filtrated in glomerulus and immediately excreted [27]. To avoid the glomerular filtration, molecules should be larger than 70,000 Da or $5 \mathrm{~nm}$ in diameter [28]. Carriers for siRNA form functional complexes with siRNA and can avoid the glomerular filtration. The size of siRNA-carrier complex can be adjusted by the physical and chemical properties of the carriers (Fig. 1). Hepatic sinusoid has relatively larger gaps than other organs. Particles smaller than $100 \mathrm{~nm}$ tend to leak out to the interstitial space of sinusoid and trapped by hepatic parenchyma cells or Kupffer cells [29]. At the same time, particles larger than $200 \mathrm{~nm}$ are entrapped by reticuloendothelial system (RES) such as liver and spleen,

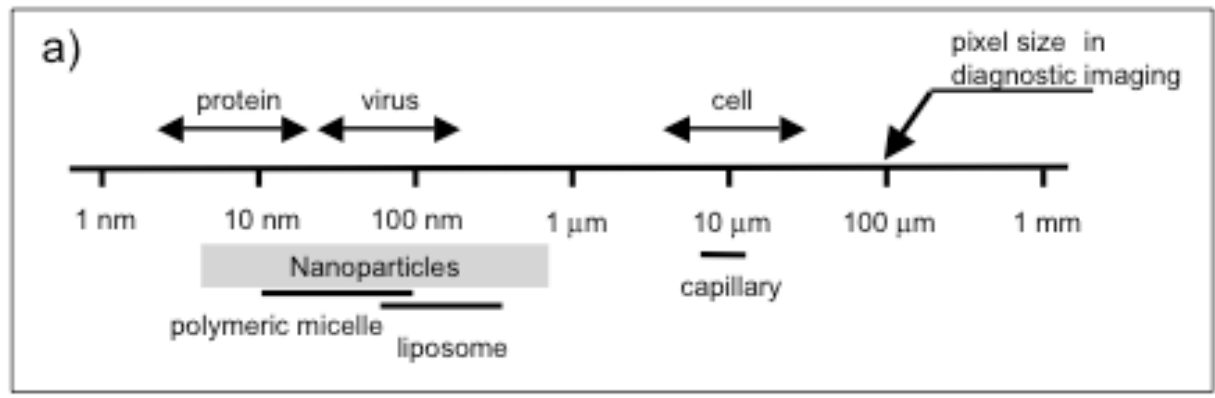

b)

b)

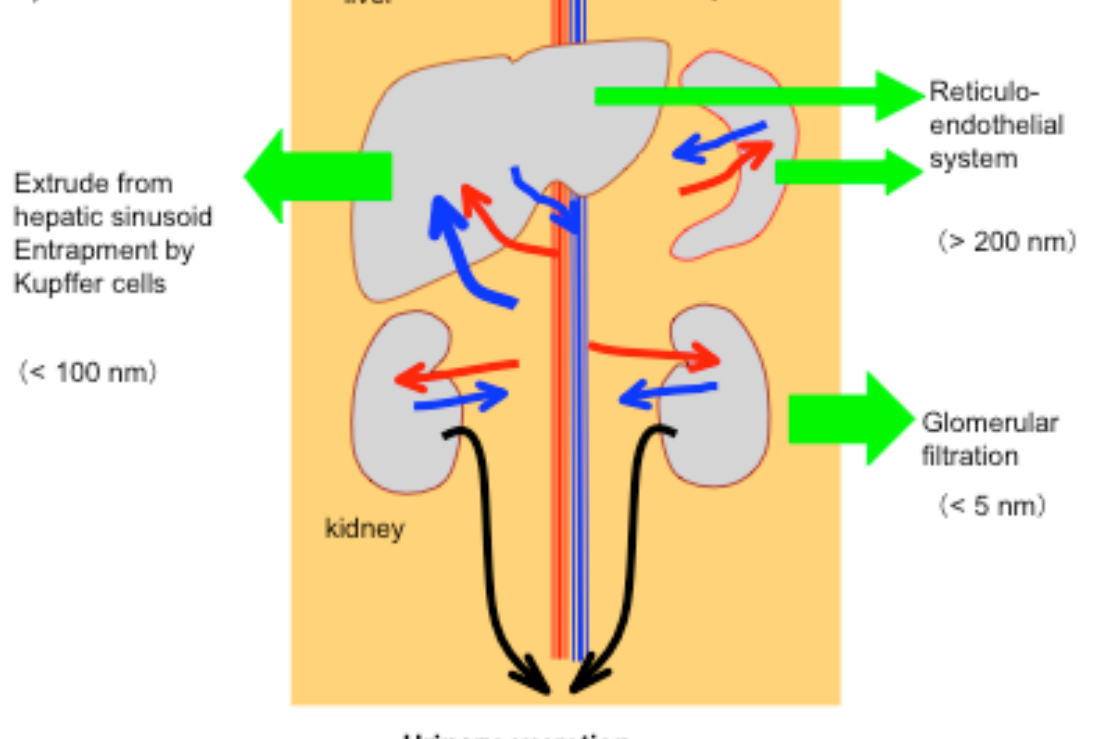

Urinary excretion

Fig. (1). Scale of nanoparticles for siRNA delivery in comparison with several components of living bodies (upper panel), and key organs to determine the kinetics of siRNA carriers. 
and rapidly removed from systemic circulation [30]. Bringing together previous reports of liposomes therefore suggests the suitable size for systemic administration is about $100 \mathrm{~nm}$ in diameter.

The scientific knowledge obtained by the research on liposomes in comparison with cells in bloodstream, especially red blood cells (RBC), has developed the biologically functional modification or the modification to produce aqueous fix layers on the surface of nanoparticles for obtaining long-circulating character-istic. It was shown that reduced RES trapping was achieved by the modification of liposomes with polyethyleneglycol (PEG) [31-35], dextran [36], or polyglycerol [37]. We previously reported that the liposomes modified with a glucuronic acid derivative, palmityl-Dglucuronide (PGlcUA) [38,39], had a long circulation time in blood stream of rats and mice. A lot of information from pharmacokinetics and DDS research could be very useful and enabled us to design the siRNA nanocarriers adapted to use in gene therapies.

\section{STABILITY IN BLOODSTREAM}

Double-stranded siRNA is relatively unstable in the presence of serum and in bloodstream; it would be degraded by RNase within a short period of time. Degradation can be delayed or avoided by chemical modification of the oligonucleotides [11,12] and/or by the formation of complexes with carriers [25]. Nucleic acids are negatively charged and electrostatically form complexes with cationic carriers. After forming of nucleotides and cationic carrier complexes, complexes are still positively charged and act in the bloodstream as cationic particles do. Cationic nanoparticles react with negatively charged molecules such as serum proteins, platelets, and RBCs in the bloodstream and form undesirable aggregates [40]. Surface modification of positively charged lipoplex by PEG can protect siRNA from RNase-mediated degradation. PEG-modification also protects lipoplex from aggregation by composing fixed water layer on the outer surface of poly-cationic lipoplex and these lipoplex acts as electrostatically neutral nanoparticles [41-43]. PEG-modified nanoparticles are also expected to solve the problems that come with the positively charged nanoparticles such as cytotoxic effects [41].

\section{CELLULAR UPTAKE OF SIRNA AND RNAi EFFECT IN TARGET CELLS}

After the delivery of siRNA to the target organs, there still remain the barriers to obtain RNAi effects, namely transmembrane delivery and appropriate intracellular localization. The two significant steps in the delivery of chemically synthesized siRNA with carriers passing through plasma membrane and disassembly of nucleotides-carrier complexes. Plasma membrane is composed of phospholipids bilayer with membrane proteins and glycolipids. Many specific modifications on the surface of carriers have been attempted to improve the efficiency of selective-transfection. Target specific molecules such as small artificial molecules, carbohydrates, peptides, aptamers, proteins and immune globulins were reported to improve the cellular uptake of the lipoplex as planned [44-48]. To achieve efficient cytosolic delivery of siRNA, liposomes fused with fusogenic viral envelope, virosomes, are reported [49].

\section{INTRACELLULAR TRANSPORTATION}

siRNA, which is taken up into the target cell cytoplasm, forms a functional complex called RISC [50-52] and degrades mRNAs, consequently suppresses the sequence specific gene expression. In these processes, siRNA must decompose from the siRNA-carrier complex in the cytoplasm to form the RISC to show RNAi effects. Chemically synthesized siRNA acts as a mRNA suppresser which directly forms RISC in cytoplasm. On the other hand, vector type siRNA such as plasmid DNA and siRNA encoded in viral nucleic acids must be transported into the cell nucleus, and then transcribed to generate the siRNA precursor RNA. The nuclear transportation efficiency of siRNA expressing vectors, especially plasmid vectors, is one of the most important steps to obtain RNAi effect using vector type siRNA. In the case of non-viral carriers, nucleotides-carrier complex must be dissociated in cytoplasm, since it is unable to pass the nuclear membrane as a complex form $[53,54]$.

\section{LIPOSOMES AND OTHER TRANS- FECTION CAR- RIERS}

Many tools for non-viral gene transfection have been developed all over the world. Gene transfection carriers can be classified into viral vectors and non-viral carriers, and the most non-viral carriers fall into the category of nanoparticles and polyethylenimine-based cationic polymers [55-57]. Nanoparticles consist of various materials and the sizes, varied from a few nanometers to several hundred nanometers. Each carrier possesses biological and pharmacological characters.

\section{LIPOSOME}

Liposomes are small spherical vesicles which consist of phospholipids bilayer. To utilize liposome for siRNA delivery, siRNA and liposome form functional complex. Cationic liposome is broadly used for gene transfection [58]. Negatively-charged nucleotides, namely siRNA, electrostatically bind with cationic liposome containing positively-charged amphiphilic molecules and form a stable complex, called lipoplex. Some articles featured the liposomes, which encapsulated nucleotides inside the vesicles [59] or with outer surface modification $[60,61]$. These liposomes protect siRNA against ribonuclease degradation [62].

\section{POLYMERIC MICELLE}

Amphiphilic block copolymers spontaneously form coreshell type polymeric micelles in aqueous media $[63,64]$. Polymeric micelles have a solid-like inner core, which serves as a potent nanocontainer of hydrophobic compounds. The chemical structures and properties of the micellar coreforming blocks significantly affect drug loading efficiency and drug release rate [65]. Similarly, hydrophilic and cationic copolymers effectively trap siRNA to make core consisting anionic siRNA and cationic blocks. Block copolymer of polyethyleneglycol and polylysine was used for this purpos $[64,66]$.

\section{OTHER NANOPARTICLES}

Nanoparticles which consist of proteinaceous biopolymer (atelocollagen, gelatin, etc.) are developed for gene transfection carrier $[67,68]$. Generally, these materials are used in pharmaceuticals, cosmetics and foods, and considered as a 
"generally regarded as safe (GRAS)" material by the United States Food and Drug Administration. Nucleotides for transfection are encapsulated in proteinaceous nanoparticles and in particles that come with surface modification molecules to advance the transfection efficiency.

In these non-viral gene transfection carriers, liposomes have been most commonly used from the early period and its potency has been well understood. We have developed that liposomes specialize for gene transfection carrier through it before. Especially, poly-cationic liposomes (PCL) based on cetyl-polyethylenimine technique have high transfection efficiency and high stability in the presence of serum in vitro and in vivo [69-71]. These liposomes also have good results on siRNA delivery and gene silencing efficiency.

\section{SIRNA-RELATED DRUGS AND DDS}

Many siRNA-related drugs have been developed in preclinical and clinical studies. These siRNA-related drugs could be classified by nucleotides, namely siRNA or siRNA encoding genes, DDS strategy in the drug form either nonviral carrier or viral vector, route of administration, and type of target diseases [72].

\section{LOCAL ADMINISTRATION}

\section{Ophthalmic Disease}

Direct intraocular administration: Age-related macular degeneration (AMD) is a form of macular degeneration observed among adults over 60 years of age, and is affecting over 15 million people in the United States alone. About 10$15 \%$ of AMD is classified into wet AMD [73]. In wet AMD, angiogenesis in and around retina and blood leaking from destructive vasculature is a causal role of blindness. Vascular endothelial growth factor (VEGF) and its receptor VEGFR have found to be directly involved in the vessel [74]. Sirna Therapeutics is developing Sirna-027, a chemically modified siRNA that targets VEGFR1. Sirna-027 was directly injected intraocular and reported to reduce neovascularization [75]. Bevasiranib is a siRNA designed to silence the gene of VEGF. Acuity Pharmaceuticals reported the encouraging Phase II results for Bevasiranib in wet AMD. Bevasiranib decreased the CNV lesions dose-dependent manner with no systemic adverse effects. Intraocular space is highly isolated environment and well-suited to assure the therapeutic potential of siRNA (Acuity Pharmaceuticals, Press release).

\section{Respiratory Disease: Inhalation}

Local administration of siRNA by inhalation can be delivered directly to pulmonary tissue and respiratory system, and effectively incorporated in target cells. Respiratory syncytial virus (RSV) infection is a great risk to young children and other immune compromised populations, such as elderly population and those who received bone marrow transplantation [76-78]. Alnylam Pharmaceuticals is developing ALNRSV01, nasal inhaler formulation of chemically modified siRNA targeted RSV. Virus specific siRNA can be used to inhibit the replication of virus in the host cells. Virus specific gene is basically believed to avoid the side effects caused by suppressing endogenously expressed gene in host cell ideally. Phase I study of inhaled formulation of ALN-RSV01 was prepared via a nebulizer and administered as intranasal spray. Alnylam reported the safety, tolerability, and pharma- cokinetics, and initiated human experimental infection study with RSV. The other siRNA targeted to viral infection examined earlier [79,80]. Developments of anti-influenza virus, siRNA for H5N1 strain of bird flu and anti-coronavirus siRNA for severe acute respiratory syndrome (SARS) have been also reported to prepare for possible epidemic in the future [81-83].

siRNA for non-infectious respiratory diseases, such as asthma and is chronic obstructive pulmonary disease (COPD), are also under development. These diseases are closely related to the inflammation, and siRNAs targeted to inflammatory cytokines are focused in some companies [84]. To deliver siRNA drugs in every detail of pulmonary tissue required for a therapeutic dosage, DDS innovations for preparing desirable size of nanoparticles and devices for administration are important.

\section{Genetic Neurodegenerative Diseases}

Genetic disorders and genetic neurodegenerative diseases are often caused by a dominant mutation in a single allele, and therefore RNAi might be a useful therapeutic strategy [85]. siRNA sequence designed for specific suppression of mutated allele was reported, but problems in delivery of the siRNA to the targeted tissue at a theoretical therapeutic dosage and in appropriate duration of RNAi effect have not yet been solved. Effective siRNA delivery systems must be established to develop the application to neuronal diseases. Firstly, transfection efficiency is a major matter for genetic disorders. Regardless of the administration route, whether the systemic administration or the local administration, administered siRNA must be incorporated directly into target cells expressing mutated gene products. Secondly, many of these neurodegenerative disorders gradually progress over the years, while the duration of RNAi effect by chemically synthesized siRNA is about 10 days at the longest. Therefore, the repeated administration safety of chemically synthesized or vector type siRNA must be examined. Although siRNA therapy for neurodegenerative disorder is quite challenging as well as other diseases at this time, aggressive researches have been conducted all over the world. Challenges to siRNA on intractable diseases (e.g. Huntington's disease, cystic fibrosis, Parkinson's diseases, spinal cord injury, amyotrophic lateral sclerosis, etc.) were reported by Sirna Therapeutics, Alnylam Pharmaceuticals Inc., and Cytrx Corporation.

\section{Hair Removal: Topical Administration}

Sirna Therapeutics reported to develop a topical delivery drug of siRNA for the application of hair removal. The target gene is human hairless gene expressed in hair root cells [86]. This cream formulized siRNA drug that penetrates the pores of the skin and is delivered to the hair follicle directly. From the view point of DDS, stability and incorporated efficiency of the siRNA might be improved by the ingredient of base.

\section{EX VIVO SIRNA ADMINISTRATION}

Acquired Immune Deficiency Syndrome (AIDS): Human Immunodeficiency Virus (HIV), the causative agent of AIDS, has infected over 40 million people. AIDS-related lymphoma is an occurrence of lymphatic cancer in about $10 \%$ of AIDS patients [87,88]. Presently, some patients who have received chemotherapy of AIDS-related lymphoma are 
on the clinical trial of siRNA therapies. In this program, the haematopoietic stem cells expressing CD34 antigen are collected from the patients' peripheral circulation prior to the chemotherapy and amplified by in vitro culturing. Multiple kinds of siRNA anti-HIV were transduced into haematopoietic stem cells with a lentivirus vector coding the antiHIV short hairpin RNA (shRNA) gene in vitro, and engineered haematopoietic stem cells were transplanted after received chemotherapy [89]. In this program, siRNA transduction has been done in vitro and sufficient dose of siRNA was introduced without systemic adverse effect. The knowledge of in vitro siRNA transduction can be applicable in this case.

\section{SYSTEMIC ADMINISTRATION}

Generally, liver is considered as a great barrier against systemically administered drugs in DDS studies. It is one of the largest organs and possesses high ability to remove foreign substances through phagocytosis by monocytes and Kupffer cells [90,91]. Hepatic sinusoid structurally differs from other blood vessels: it has relatively large fenestrae, which allows molecules and particles smaller than $100 \mathrm{~nm}$ to leak from the vessel to the extravascular cavity. From the different standpoint, liver is a glamorous organ in drug delivery. Based on the characteristics of liver mentioned above, almost all DDS carriers injected could be accumulated by systemic administration. Furthermore, surface modification with specific glycolipids having mannose or galactose terminal enhances the accumulation in liver $[92,93]$. In the view of this pharmacological knowledge, siRNA targeting liver should be the most advanced stage of DDS-based systemic administration. Systemic administration is also applicable for diabetes, cancer and so on.

\section{Viral Hepatitis}

A large number of people around the world is disturbed by chronic viral hepatitis induced by hepatitis B virus (HBV) and by hepatitis $\mathrm{C}$ virus (HCV), and the number of patients is increasing [94-97]. Benitec Limited and Sirna Therapeutics are challenging to develop siRNA drug for viral hepatitis [98]. As mentioned above, liver is an ideal organ for systemic administration, such evidence however mainly established and proved in small animal models [98]. Ensuring safety of high siRNA dose enough to eliminate the entire virus in liver should be taken carefully into our consideration when applying it for human therapy.

\section{Hyperlipidaemia and Diabetes}

Alnylam Pharmaceuticals is developing siRNA drug antiapolipoprotein B (ApoB) for the treatment of hyperlipidaemia. They reported the RNAi-mediated ApoB gene silencing in non-human primates cynomolgus monkeys [99,100]. In this case, they used siRNA-encapsulated liposomes with 77$83 \mathrm{~nm}$ diameters. As a result, ApoB and low-density lipoprotein (LDL) in serum were suppressed from $24 \mathrm{~h}$ post administration and the effect was sustained 10 days post administration. Sirna therapeutics is developing anti-PTP-1B siRNA. PTP-1B is considered as a therapeutic target molecule for type II diabetes and plays an important role in insulin resistance [101]. They prepared chemically modified siRNA target PTP-1B and encapsulated in PEG modified liposomes. This drug was administrated to mouse intravenously and
PTP-1B expression in liver was suppressed 67\% (reported in the corporation website).

\section{Cancer}

Many candidate genes for therapeutic use of siRNA in cancer were reported previously $[3,102]$. There are many gene mutations in cancer cells: Several single nucleotide mutant forms of p53 and ras are frequently mutated in human cancer and chromosomal translocation in leukaemia and lymphoma are well known $[3,103,104]$. Many gene products functionally associated with the growth and malignancy of cancers in vitro and in vivo, e.g. anti-apoptotic proteins, cytoskeleton proteins, signal-transducing proteins, growth factors, and receptors, have been reported $[102,105,106]$. Efficient validation of siRNA against cancer, however, is not achieved especially in human. One of the most serious problems for the achievement is the lack of efficient delivery system of siRNA to the targeting genes.

Tumor angiogenesis is a fascinating target of drug delivery system. We previously developed drug delivery system targeted tumor angiogenesis by use of liposomes modified by target specific peptide ligands [107-109]. Intradigm Corporation and Sirna therapeutics are developing siRNA targeted VEGFR. The siRNA carrier of Intradigm is a polymeric micelle with positively charged core and PEG chain, outer surface is modified with peptide which selectively binds to tumor neovasculature.

\section{PERSPECTIVE}

siRNA technology has been rapidly developed since chemically synthesized siRNA was reported in 2001. There are a number of glamorous targets in therapeutic use of siRNA and its derivatives. Different from the conventional small molecular drugs, siRNA cannot be used without appropriate gene carriers or vectors. We are now developing real-time in vivo imaging system of gene carriers, such as liposomes by use of positron-emission tomography (PET). This technology should support the development of various siRNA carriers. Gene delivery system in either local or systemic administration of siRNA should be a key player in successful siRNA therapy.

\section{REFERENCES}

[1] Elbashir SM, Harborth J, Lendeckel W, Yalcin A, Weber K, Tuschl T. Duplexes of 21-nucleotide RNAs mediate RNA interference in cultured mammalian cells. Nature 2001; 411: 494-8.

[2] Caplen NJ, Parrish S, Imani F, Fire A, Morgan RA. Specific inhibition of gene expression by small double-stranded RNAs in invertebrate and vertebrate systems. Proc Natl Acad Sci USA 2001; 98: 9742-7.

[3] Uprichard SL. The therapeutic potential of RNA interference. FEBS Lett 2005; 579: 5996-6007.

[4] Haasnoot PC, Cupac D, Berkhout B. Inhibition of virus replication by RNA interference. J Biomed Sci 2003; 10: 607-16.

[5] Wood MJ, Trulzsch B, Abdelgany A, Beeson D. Therapeutic gene silencing in the nervous system. Human Mol Genetics 2003; 12: R279-84.

[6] Buckingham SD, Esmaeili B, Wood M, Sattelle DB. RNA interference: from model organisms towards therapy for neural and neuromuscular disorders. Human Mol Genetics 2004; 13: R275-88.

[7] Goodchild J. Oligonucleotide therapeutics: 25 years agrowing. Curr Opin Mol Therapeut 2004; 6: 120-8.

[8] Khan AU. Ribozyme: a clinical tool. Clinica chimica acta; Int J Clin Chem 2006; 367: 20-7.

[9] Marwick C. First "antisense" drug will treat CMV retinitis. JAMA 1998; 280: 871 . 
[10] Aboul-Fadl T. Antisense oligonucleotides: the state of the art. Curr Med Chem 2005; 12: 2193-214.

[11] Chiu YL, Rana TM. siRNA function in RNAi: a chemical modification analysis. RNA 2003; 9: 1034-48.

[12] Zhang HY, Du Q, Wahlestedt C, Liang Z. RNA Interference with chemically modified siRNA. Curr Topics Med Chem 2006; 6: 893900.

[13] Layzer JM, McCaffrey AP, Tanner AK, Huang Z, Kay MA, Sullenger BA. In vivo activity of nuclease-resistant siRNAs. RNA 2004; 10: 766-71.

[14] Bartlett DW, Davis ME. Effect of siRNA nuclease stability on the in vitro and in vivo kinetics of siRNA-mediated gene silencing. Biotechnol Bioeng 2006; 97: 909-21

[15] Sui G, Soohoo C, Affar el B, Gay F, Shi Y, Forrester WC, et al. A DNA vector-based RNAi technology to suppress gene expression in mammalian cells. Proc Natl Acad Sci USA 2002; 99: 5515-20.

[16] Brummelkamp TR, Bernards R, Agami R. A system for stable expression of short interfering RNAs in mammalian cells. Science 2002; 296: 550-3.

[17] Yu JY, DeRuiter SL, Turner DL. RNA interference by expression of short-interfering RNAs and hairpin RNAs in mammalian cells. Proc Natl Acad Sci USA 2002; 99: 6047-52.

[18] Kawasaki H, Taira K. Short hairpin type of dsRNAs that are controlled by tRNA(Val) promoter significantly induce RNAimediated gene silencing in the cytoplasm of human cells. Nucl Acids Res 2003; 31: 700-7.

[19] Zentilin L, Giacca M. In vivo transfer and expression of genes coding for short interfering RNAs. Curr Pharma Biotechnol. 2004; 5: 341-7.

[20] Pardridge WM. Intravenous, non-viral RNAi gene therapy of brain cancer. Exp Opin Biol Ther 2004; 4: 1103-13.

[21] Chang K, Elledge SJ, Hannon GJ. Lessons from Nature: microRNA-based shRNA libraries. Nat Methods 2006; 3: 707-14.

[22] Ong ST, Li F, Du J, Tan YW, Wang S. Hybrid cytomegalovirus enhancer-h1 promoter-based plasmid and baculovirus vectors mediate effective RNA interference. Human Gene Ther 2005; 16: 1404-12.

[23] Demeneix B, Behr J, Boussif O, Zanta MA, Abdallah B, Remy J. Gene transfer with lipospermines and polyethylenimines. Adv Drug Deliv Rev 1998; 30: 85-95.

[24] Hosseinkhani H, Tabata Y. Self assembly of DNA nanoparticles with polycations for the delivery of genetic materials into cells. J Nanosci Nanotech 2006; 6: 2320-8.

[25] Spagnou S, Miller AD, Keller M. Lipidic carriers of siRNA: differences in the formulation, cellular uptake, and delivery with plasmid DNA. Biochemistry 2004; 43: 13348-56.

[26] Lubec G, Kuhn K, Latzka U, Reale E. Glomerular permeability for proteins of high molecular weight entrapped in liposomes. Renal Physiol 1981; 4: 131-6.

[27] van de Water FM, Boerman OC, Wouterse AC, Peters JG, Russel FG, Masereeuw R. Intravenously administered short interfering RNA accumulates in the kidney and selectively suppresses gene function in renal proximal tubules. Drug Metabol Dispos 2006; 34: 1393-7.

[28] Latta H, Fligiel S. Mesangial fenestrations, sieving, filtration, and flow. Laboratory investigation; J Tech Methods Pathol 1985; 52: 591-8.

[29] Wisse E. An electron microscopic study of the fenestrated endothelial lining of rat liver sinusoids. J Ultrastruct Res 1970; 31: 125-50.

[30] Kiwada H, Matsuo H, Harashima H. Identification of proteins mediating clearance of liposomes using a liver perfusion system. Adv Drug Deliv Rev 1998; 32: 61-79.

[31] Klibanov AL, Maruyama K, Torchilin VP, Huang L. Amphipathic polyethyleneglycols effectively prolong the circulation time of liposomes. FEBS Lett 1990; 268: 235-7.

[32] Blume G, Cevc G. Liposomes for the sustained drug release in vivo. Biochim Biophys Acta 1990; 1029: 91-7.

[33] Senior J, Delgado C, Fisher D, Tilcock C, Gregoriadis G. Influence of surface hydrophilicity of liposomes on their interaction with plasma protein and clearance from the circulation: studies with poly(ethylene glycol)-coated vesicles. Biochim Biophys Acta 1991; 1062: 77-82.

[34] Allen TM, Hansen C, Martin F, Redemann C, Yau-Young A. Liposomes containing synthetic lipid derivatives of poly(ethylene glycol) show prolonged circulation half-lives in vivo. Biochim Biophys Acta 1991; 1066: 29-36.
[35] Papahadjopoulos D, Allen TM, Gabizon A, Mayhew E, Matthay K, Huang SK, et al. Sterically stabilized liposomes: improvements in pharmacokinetics and antitumor therapeutic efficacy. Proc Natl Acad Sci USA 1991; 88: 11460-4.

[36] Mumtaz S, Ghosh PC, Bachhawat BK. Design of liposomes for circumventing the reticuloendothelial cells. Glycobiol 1991; 1: 505-10.

[37] Yuda T, Maruyama K, Iwatsuru M. Prolongation of liposome circulation time by various derivatives of polyethyleneglycols. Biol Pharm Bull 1996; 19: 1347-51.

[38] Namba Y, Sakakibara T, Masada M, Ito F, Oku N. Glucuronatemodified liposomes with prolonged circulation time. Chem Pharm Bull 1990; 38: 1663-6.

[39] Oku N, Namba Y, Okada S. Tumor accumulation of novel RESavoiding liposomes. Biochim Biophys Acta 1992; 1126: 255-60.

[40] Schreier H, Gagne L, Bock T, Erdos GW, Druzgala P, Conary JT, et al. Physicochemical properties and in vitro toxicity of cationic liposome cDNA complexes. Pharm Acta Helvet 1997; 72: 215-23.

[41] Meyer O, Kirpotin D, Hong K, Sternberg B, Park JW, Woodle MC, et al. Cationic liposomes coated with polyethylene glycol as carriers for oligonucleotides. J Biol Chem 1998; 273: 15621-7.

[42] Zhang Y, Anchordoquy TJ. The role of lipid charge density in the serum stability of cationic lipid/DNA complexes. Biochim Biophys Acta 2004; 1663: 143-57.

[43] Sakurai F, Nishioka T, Yamashita F, Takakura Y, Hashida M. Effects of erythrocytes and serum proteins on lung accumulation of lipoplexes containing cholesterol or DOPE as a helper lipid in the single-pass rat lung perfusion system. Eur J Pharm Biopharm 2001; 52: $165-72$.

[44] Read ML, Logan A, Seymour LW. Barriers to gene delivery using synthetic vectors. Adv Genetics 2005; 53: 19-46.

[45] Lu PY, Xie F, Woodle MC. In vivo application of RNA interference: from functional genomics to therapeutics. Adv Genetics 2005; 54: 117-42.

[46] Inoue A, Sawata SY, Taira K. Molecular design and delivery of siRNA. J Drug Target 2006; 14: 448-55.

[47] Hogrefe RI, Lebedev AV, Zon G, Pirollo KF, Rait A, Zhou Q, et al. Chemically modified short interfering hybrids (siHYBRIDS): nanoimmunoliposome delivery in vitro and in vivo for RNAi of HER-2. Nucleosides Nucleotides Nucl Acids. 2006; 25: 889-907.

[48] Khoury M, Louis-Plence P, Escriou V, Noel D, Largeau C, Cantos $\mathrm{C}$, et al. Efficient new cationic liposome formulation for systemic delivery of small interfering RNA silencing tumor necrosis factor alpha in experimental arthritis. Arthritis Rheumat 2006; 54: 186777.

[49] Huckriede A, De Jonge J, Holtrop M, Wilschut J. Cellular delivery of siRNA mediated by fusion-active virosomes. J Liposome Res 2007; $17: 39-47$.

[50] Agrawal N, Dasaradhi PV, Mohmmed A, Malhotra P, Bhatnagar RK, Mukherjee SK. RNA interference: biology, mechanism, and applications. Microbiol Mol Biol Rev 2003; 67: 657-85.

[51] Schwarz DS, Hutvagner G, Du T, Xu Z, Aronin N, Zamore PD. Asymmetry in the assembly of the RNAi enzyme complex. Cell 2003; 115: 199-208.

[52] Martinez J, Patkaniowska A, Urlaub H, Luhrmann R, Tuschl T. Single-stranded antisense siRNAs guide target RNA cleavage in RNAi. Cell 2002; 110: 563-74.

[53] Farhood H, Serbina N, Huang L. The role of dioleoyl phosphatidylethanolamine in cationic liposome mediated gene transfer. Biochim Biophys Acta 1995; 1235: 289-95.

[54] Noguchi A, Furuno T, Kawaura C, Nakanishi M. Membrane fusion plays an important role in gene transfection mediated by cationic liposomes. FEBS Lett 1998; 433: 169-73.

[55] Putnam D, Doody A. RNA-interference effectors and their delivery.Crit Rev Ther Drug Carrier Syst. 2006; 23: 137-64.

[56] Aigner A. Gene silencing through RNA interference (RNAi) in vivo: strategies based on the direct application of siRNAs. J Biotechnol 2006; 124: 12-25.

[57] Gilmore IR, Fox SP, Hollins AJ, Akhtar S. Delivery strategies for siRNA-mediated gene silencing. Curr Drug Deliv 2006; 3: 147-5.

[58] Sioud M, Sorensen DR. Cationic liposome-mediated delivery of siRNAs in adult mice. Biochem Biophys Res Commun 2003; 312: 1220-5.

[59] Jeffs LB, Palmer LR, Ambegia EG, Giesbrecht C, Ewanick S, MacLachlan I. A scalable, extrusion-free method for efficient 
liposomal encapsulation of plasmid DNA. Pharm Res 2005; 22: 362-72.

[60] Bouxsein NF, McAllister CS, Ewert KK, Samuel CE, Safinya CR. Structure and gene silencing activities of monovalent and pentavalent cationic lipid vectors complexed with siRNA. Biochemistry 2007; 46: 4785-92.

[61] Martin-Herranz A, Ahmad A, Evans HM, Ewert K, Schulze U, Safinya CR. Surface functionalized cationic lipid-DNA complexes for gene delivery: PEGylated lamellar complexes exhibit distinct DNA-DNA interaction regimes. Biophys J 2004; 86: 1160-8.

[62] Miyawaki-Shimizu K, Predescu D, Shimizu J, Broman M, Predescu S, Malik AB. siRNA-induced caveolin-1 knockdown in mice increases lung vascular permeability via the junctional pathway. Am J Physiol 2006; 290: L405-13.

[63] Wolfert MA, Schacht EH, Toncheva V, Ulbrich K, Nazarova O, Seymour LW. Characterization of vectors for gene therapy formed by self-assembly of DNA with synthetic block co-polymers. Human Gene Ther 1996; 7: 2123-33.

[64] Miyata K, Kakizawa Y, Nishiyama N, Yamasaki Y, Watanabe T, Kohara M, et al. Freeze-dried formulations for in vivo gene delivery of PEGylated polyplex micelles with disulfide crosslinked cores to the liver. J Control Release 2005; 109: 15-23.

[65] Kakizawa Y, Furukawa S, Ishii A, Kataoka K. Organic-inorganic hybrid-nanocarrier of siRNA constructing through the selfassembly of calcium phosphate and PEG-based block aniomer. J Control Release 2006; 111: 368-70.

[66] Miyata K, Kakizawa Y, Nishiyama N, Harada A, Yamasaki Y, Koyama $\mathrm{H}$, et al. Block catiomer polyplexes with regulated densities of charge and disulfide cross-linking directed to enhance gene expression. J Am Chem Soc 2004; 126: 2355-61.

[67] Honma K, Miyata T, Ochiya T. The role of atelocollagen-based cell transfection array in high-throughput screening of gene functions and in drug discovery. Curr Drug Discov Technol 2004; 1 : 287-94.

[68] Matsumoto G, Kushibiki T, Kinoshita Y, Lee U, Omi Y, Kubota E, et al. Cationized gelatin delivery of a plasmid DNA expressing small interference RNA for VEGF inhibits murine squamous cell carcinoma. Cancer Sci 2006; 97: 313-21.

[69] Li W, Ishida T, Okada Y, Oku N, Kiwada H. Increased gene expression by cationic liposomes (TFL-3) in lung metastases following intravenous injection. Biol Pharm Bull 2005; 28: 701-6.

[70] Oku N, Yamazaki Y, Matsuura M, Sugiyama M, Hasegawa M, Nango M. A novel non-viral gene transfer system, polycation liposomes. Adv Drug Deliv Rev 2001; 52: 209-18.

[71] Yamazaki Y, Nango M, Matsuura M, Hasegawa Y, Hasegawa M, Oku N. Polycation liposomes, a novel nonviral gene transfer system, constructed from cetylated polyethylenimine. Gene Ther 2000; 7: 1148-55.

[72] Behlke MA. Progress towards in vivo use of siRNAs. Mol Ther 2006; 13: 644-70

[73] Kulkarni AD, Kuppermann BD. Wet age-related macular degeneration. Adv Drug Deliv Rev 2005; 57: 1994-2009.

[74] Witmer AN, Vrensen GF, Van Noorden CJ, Schlingemann RO. Vascular endothelial growth factors and angiogenesis in eye disease. Progr Retinal Eye Res 2003; 22: 1-29.

[75] Shen J, Samul R, Silva RL, Akiyama H, Liu H, Saishin Y, et al. Suppression of ocular neovascularization with siRNA targeting VEGF receptor 1. Gene Ther 2006; 13: 225-34.

[76] Bitko V, Musiyenko A, Shulyayeva O, Barik S. Inhibition of respiratory viruses by nasally administered siRNA. Nat Med 2005; 11 : 50-5.

[77] Couch RB, Englund JA, Whimbey E. Respiratory viral infections in immunocompetent and immunocompromised persons. Am J Med 1997; 102: 2-9; discussion 25-6.

[78] Ebbert JO, Limper AH. Respiratory syncytial virus pneumonitis in immunocompromised adults: clinical features and outcome. Respiration; Int Rev Thoracic Dis 2005; 72: 263-9.

[79] Ge Q, Filip L, Bai A, Nguyen T, Eisen HN, Chen J. Inhibition of influenza virus production in virus-infected mice by RNA interference. Proc Natl Acad Sci USA 2004; 101: 8676-81.

[80] Tompkins SM, Lo CY, Tumpey TM, Epstein SL. Protection against lethal influenza virus challenge by RNA interference in vivo. Proc Natl Acad Sci USA 2004; 101: 8682-6.

[81] Li BJ, Tang Q, Cheng D, Qin C, Xie FY, Wei Q, et al. Using siRNA in prophylactic and therapeutic regimens against SARS coronavirus in Rhesus macaque. Nat Med 2005; 11: 944-51.
[82] Li T, Zhang Y, Fu L, Yu C, Li X, Li Y, et al. siRNA targeting the leader sequence of SARS-CoV inhibits virus replication. GeneTher 2005; 12: 751-61.

[83] Ni B, Shi X, Li Y, Gao W, Wang X, Wu Y. Inhibition of replication and infection of severe acute respiratory syndrome-associated coronavirus with plasmid-mediated interference RNA. Antiviral Ther 2005; 10: 527-33.

[84] Schiffelers RM, Xu J, Storm G, Woodle MC, Scaria PV. Effects of treatment with small interfering RNA on joint inflammation in mice with collagen-induced arthritis. Arthritis Rheumat 2005; 52: 1314-8.

[85] Davidson BL, Paulson HL. Molecular medicine for the brain: silencing of disease genes with RNA interference. Lancet Neurol 2004; 3 : 145-9.

[86] Djabali K, Zlotogorski A, Metzker A, Ben-Amitai D, Christiano AM. Interaction of hairless and thyroid hormone receptor is not involved in the pathogenesis of atrichia with papular lesions. Exp Dermatol 2004; 13: 251-6.

[87] Davis BM, Humeau L, Dropulic B. In vivo selection for human and murine hematopoietic cells transduced with a therapeutic MGMT lentiviral vector that inhibits HIV replication. Mol Ther 2004; 9: 160-72.

[88] Dropulic B. Lentivirus in the clinic. Mol Ther 2001; 4: 511-2.

[89] Michienzi A, Castanotto D, Lee N, Li S, Zaia JA, Rossi JJ. RNAmediated inhibition of HIV in a gene therapy setting. Ann N Y Acad Sci 2003; 1002: 63-71

[90] Cay O, Kruskal JB, Nasser I, Thomas P, Clouse ME. Liver metastases from colorectal cancer: drug delivery with liposomeencapsulated doxorubicin. Radiol 1997; 205: 95-101.

[91] Litzinger DC, Brown JM, Wala I, Kaufman SA, Van GY, Farrell $\mathrm{CL}$, et al. Fate of cationic liposomes and their complex with oligonucleotide in vivo. Biochim Biophys Acta 1996; 1281: 139-49.

[92] Murahashi N, Sasaki A. In vivo behavior of liposomes modified with a novel galactosyllipid derivative. Biol Pharm Bull 1996; 19: 418-23.

[93] Sasaki A, Murahashi N, Yamada H, Morikawa A. Syntheses of novel galactosyl ligands for liposomes and their accumulation in the rat liver. Biol Pharm Bull 1994; 17: 680-5.

[94] Kao JH, Chen DS. Global control of hepatitis B virus infection. Lancet Infect Dis 2002; 2: 395-403.

[95] Kao JH, Chen DS. Changing disease burden of hepatocellular carcinoma in the Far East and Southeast Asia. Liver Int 2005; 25: 696-703.

[96] Williams R. Global challenges in liver disease. Hepatology (Baltimore, Md.) 2006; 44: 521-6.

[97] Grimm D, Kay MA. Therapeutic short hairpin RNA expression in the liver: viral targets and vectors. Gene Ther 2006; 13: 563-75.

[98] Morrissey DV, Lockridge JA, Shaw L, Blanchard K, Jensen K, Breen $\mathrm{W}$, et al. Potent and persistent in vivo anti-HBV activity of chemically modified siRNAs. Nat Biotech 2005; 23: 1002-7.

[99] Soutschek J, Akinc A, Bramlage B, Charisse K, Constien R, Donoghue $\mathrm{M}$, et al. Therapeutic silencing of an endogenous gene by systemic administration of modified siRNAs. Nature 2004; 432: 173-8.

[100] Zimmermann TS, Lee AC, Akinc A, Bramlage B, Bumcrot D, Fedoruk MN, et al. RNAi-mediated gene silencing in non-human primates. Nature 2006; 441: 111-4.

[101] Qiu W, Avramoglu RK, Dube N, Chong TM, Naples M, Au C, et $a l$. Hepatic PTP-1B expression regulates the assembly and secretion of apolipoprotein B-containing lipoproteins: evidence from protein tyrosine phosphatase-1B overexpression, knockout, and RNAi studies. Diabetes 2004; 53: 3057-66.

[102] Gartel AL, Kandel ES. RNA interference in cancer. Biomol Engineering 2006; 23: 17-34.

[103] Thomas M, Greil J, Heidenreich O. Targeting leukemic fusion proteins with small interfering RNAs: recent advances and therapeutic potentials. Acta Pharmacol Sin 2006; 27: 273-81.

[104] Dutton A, Burns AT, Young LS, Murray PG. Targeting cellular FLICE-like inhibitory protein as a novel approach to the treatment of Hodgkin's lymphoma. Exp Rev Anticancer Ther 2006; 6: 911-9.

[105] Pai SI, Lin YY, Macaes B, Meneshian A, Hung CF, Wu TC. Prospects of RNA interference therapy for cancer. Gene Ther 2006; 13: 464-77.

[106] Pushparaj PN, Melendez AJ. Short interfering RNA (siRNA) as a novel therapeutic. Clin Exp Pharmacol Physiol 2006; 33: 504-10. 
[107] Asai T, Nagatsuka M, Kuromi K, Yamakawa S, Kurohane K, Ogino $\mathrm{K}$, et al. Suppression of tumor growth by novel peptides homing to tumor-derived new blood vessels. FEBS letters. 2002; 510: 206-10.
[108] Oku N, Asai T, Kurohane K, Watanabe K, Kuromi K, Namba Y, et al. Cancer antineovascular therapy. Cell Mol Biol Lett 2002; 7: 247-8.

[109] Oku N, Asai T, Watanabe K, Kuromi K, Nagatsuka M, Kurohane $\mathrm{K}$, et al. Anti-neovascular therapy using novel peptides homing to angiogenic vessels. Oncogene 2002; 21: 2662-9. 